\title{
Substitutions of Soybean Meal with Enriched Palm Kernel Meal in Laying Hens Diet
}

\author{
Sinurat AP, Purwadaria T, Ketaren PP, Pasaribu T \\ Indonesian Research Institute for Animal Production, PO Box 221, Bogor 16002, Indonesia \\ E-mail: arnoldps57@yahoo.com
}

(Diterima 14 Juli 2014 ; disetujui 7 September 2014)

\begin{abstract}
ABSTRAK
Sinurat AP, Purwadaria T, Ketaren, PP, Pasaribu T. 2014. Penggantian bungkil kedelai dalam ransum ayam petelur dengan bungkil inti sawit yang sudah diperkaya nilai gizinya. JITV 19(3): 184-192. DOI: http://dx.doi.org/10.14334/jitv.v19i3.1081

Serangkaian penelitian dilakukan untuk menggantikan bungkil kedelai (SBM) dengan bungkil inti sawit (PKC) dalam ransum ayam petelur. Tahap pertama dilakukan untuk meningkatkan kandungan protein dan asam amino BIS melalui proses fermentasi dan dilanjutkan dengan penambahan enzim untuk meningkatkan kecernaan asam amino. Selanjutnya dilakukan uji biologis untuk mengetahui efektifitas PKC yang sudah difermentasi (FPKC) dan ditambahkan enzim (EFPKC) untuk menggantikan SBM didalam ransum ayam petelur. Nilai energy (AME) dari PKC, FPKC dan EFPKC diukur dengan menggunakan ayam broiler dan dilanjutkan dengan pengukuran nilai asam amino tercerna pada ileal (IAAD). Nilai AME dan IAAD dari EFPKC kemudian digunakan untuk meramu ransum penelitian. Ransum diberikan pada ayam petelur umur 51 minggu selama 8 minggu. Lima (5) jenis ransum disusun dengan kandungan gizi yang sama, tetapi SBM diganti dengan EFPKC secara bertingkat. Ransum perlakuan terdiri dari 1. Kontrol (tanpa EFPKC), 2. 25\% SBM dalam ransum Kontrol diganti dengan EFPKC, 3. 50\% SBM dalam ransum Kontrol diganti dengan EFPKC, 4. 75\% SBM dalam ransum Kontrol diganti dengan EFPKC and 5. 100\% of SBM dalam ransum Kontrol diganti dengan EFPKC. Setiap ransum perlakuan diberikan pada 24 ekor ayam (6 ulangan, 4 ekor/ulangan). Hasil penelitian menunjukkan bahwa fermentasi PKC meningkatkan protein kasar dan asam amino, kecuali threonin dan arginin, tetapi menurunkan AME. Penambahan enzim pada FPKC meningkatkan nilai IAAD. Akan tetapi hanya enzim BS4 yang dapat meningkatkan nilai AME pada EFPKC. Uji biologis menunjukkan bahwa sekitar 25 hingga $50 \%$ bungkil kedelai didalam ransum dapat diganti dengan bungkil inti sawit yang sudah difermentasi dan ditambahkan enzim tanpa meyebabkan gangguan yang berarti pada performan ayam petelur.
\end{abstract}

Kata Kunci: Bungkil Kedelai, Bungkil Inti Sawit, Fermentasi, Enzim, Produksi Telur

\section{ABSTRACT}

Sinurat AP, Purwadaria T, Ketaren, PP, Pasaribu T. 2014. Substitutions of soybean meal with enriched palm kernel meal in laying hens diet. JITV 19(3): 184-192. DOI: http://dx.doi.org/10.14334/jitv.v19i3.1081

A series of experiment was conducted in order to substitute soybean meal (SBM) with palm kernel cake (PKC) as a protein source in laying hens diet. First experiment was to increase its protein and amino acids content by fermentation process and followed by enzymes supplementation to improve nutrient digestibilities. Second experiment was conducted to evaluate the effectiveness of enzyme- supplemented fermented palm kernel cake (EFPKC) to replace SBM in laying hens diet. The energy (AME) of the PKC, the fermented PKC (FPKC) and the EFPKC was measured by ileal amino acids digestibility (IAAD) in broilers. The AME and the IAAD values of the EFPKC were used for diet formulation in the feeding trial. A feeding trial was performed in laying hens, aged 51 weeks for 8 weeks egg production. Five diets with different levels of substitution of SBM with EFPKC but similar nutrient contents were formulated, i.e.: 1. Control (without EFPKC), 2. 25\% of SBM in control diet substituted with EFPKC, 3. 50\% of SBM in control diet substituted with EFPKC, $4.75 \%$ of SBM in control diet substituted with EFPKC and 5. 100\% of SBM in control diet substituted with EFPKC. Each diet was fed to 24 hens (6 replicates of 4 birds/ replicate). Results of the experiment showed that the fermentation of PKC increased the crude protein and most of the amino acids contents except the threonine and arginine, but decreased its AME. Supplementation of enzymes (BS4 or CE) improved the ileal amino acid digestibilities of the fermented PKC. However, only BS4 enzymes increased the AME of the EFPKC. About $25 \%$ to $50 \%$ of the SBM in the diet could be substituted with the EFPKC without any detrimental effect on the performances of laying hens.

Key Words: Soybean Meal, Palm Kernel Cake, Fermentation, Enzyme, Egg Production

\section{INTRODUCTION}

Soybean meal (SBM) is commonly used as a protein source in poultry feed due to its high protein and amino acids contents and digestibilities. The increasing demand for SBM due to the increasing world poultry feed production, stimulate the increase of SBM and the feed prices. Therefore, some attemps have been 
reported to replace the SBM with some non conventional feedstuffs such as rapeseed meal (Leeson et al. 1987; Ciurescu 2009), sunflower seed meal (Shi et al. 2012), fermented cotton seed meal (Azman \& Yilmaz 2005) and peanut meal (Pesti et al. 2003).

Palm kernel cake (PKC) is produced abundantly in tropical countries such as Indonesia, Malaysia, Nigeria and other countries. The world PKC production is estimated at 8,345 million ton in year 2014. The PKC is a by product of palm kernel oil production, mostly produced by mechanical extraction of the oil from the palm kernel seed. The nutritive values of the PKC, including its digestible amino acids values have been reported by some authors (Nwokolo et al. 1977; Onwudike 1986; Sue and Awaludin 2005; Sundu et al. 2006). The protein, amino acids and the digestible amino acids of the PKC are much lower than the SBM. The crude protein, lysine and methionine contents of SBM varies from $42.74-50.71 \%, 2.0-3.36 \%$ and 0.58 $0.90 \%$, respectively (Clarke and Wiseman 1999) while the crude protein, lysine and methionine contents of the PKC varies from $14-21 \%, 0.59-0.69 \%$ and $0.30-0.47 \%$, respectively. Therefore, the replacement of SBM with PKM in poultry diet formulation will disturb the nutrient balances of the diet, unless other feed ingredients or synthetic nutrients such as essential amino acids are adjusted.

Some efforts have been reported to increase the protein and amino acids contents of the PKC and its nutrients digestibility in order to increase the inclusion of PKC in the diet and reduce the inclusion of the SBM in poultry diet. Iyayi \& Aderolu (2004) improved the crude protein of the PKC from 16.0 to $21.11 \%$ and the metabolizable energy (ME) from $2610 \mathrm{kcal} / \mathrm{kg}$ to 2840 $\mathrm{kcal} / \mathrm{kg}$ by fermentation with Trichoderma viridae. Supplementation of enzyme in the diet containing PKC have been reported to increase the $\mathrm{TME}_{\mathrm{n}}$ of the diets (Iyayi \& Davies 2005; Chong et al. 2008). Recently, Saenphoom et al. (2013) reported that enzyme supplementation (mainly cellulase and mannanase) increased the TME and $\mathrm{TME}_{\mathrm{n}}$ in PKC. In order to improve the nutrient contents and digestibility of the PKC, a study was designed to ferment the PKC, followed with exogenous enzyme supplementation. The inclusion of the processed PKC in poultry diet is expected to reduce the inclusion level of SBM in the diet.

\section{MATERIALS AND METHODS}

\section{Improvement of the nutritive values of the palm kernel cake}

Palm kernel cake (PKC) used in this study was obtained from a commercial feed mill in Bekasi, West
Java. Prior to the treatments, the PKC was sieved with 2 $\mathrm{mm}$ mesh in order to reduce it's shell contents as described by Sinurat et al. (2013) and then fermented with Aspergillus niger in attempt to increase its protein and amino acids content following the procedures described by Pasaribu (2013 unpublised). The PKC and the fermented PKC (FPKC) were supplemented with 2 (two) kind of enzymes, i.e., a crude enzymes produced in our laboratory (BS4) at $20 \mathrm{ml} / \mathrm{kg}$ feedstuff and a commercial multi enzymes (CE) at $2 \mathrm{~g} / \mathrm{kg}$ feedstuff. The commercial enzymes according to the official brochure consists of cellulase $6,000 \mathrm{U} / \mathrm{g}$, xylanase $10,000 \mathrm{U} / \mathrm{g}$, glucanase $700 \mathrm{U} / \mathrm{g}$, phytase $400 \mathrm{U} / \mathrm{g}, \alpha$ amylase $700 \mathrm{U} / \mathrm{g}$, protease $3,000 \mathrm{U} / \mathrm{g}$, pectinase $70 \mathrm{U} / \mathrm{g}$ and lipase $5 \mathrm{U} / \mathrm{g}$ while the BS4 enzymes consist of $\beta$ mannanase, CMCase (cellulase), $\beta$-mannosidase, $\beta$ glucosidase and $\alpha$-galactosidase (Purwadaria et al. 2003). Assay on saccharification activity on palm kernel meal of the commercial enzyme and the BS4 enzyme was similar, i.e., $632.1 \mathrm{u} / \mathrm{ml}$ and $641.1 \mathrm{unit} / \mathrm{g}$, respectively (Pasaribu et al. 2009). Previous report indicated that $2 \mathrm{~g}$ CE enzyme/kg or $20 \mathrm{ml} \mathrm{BS} 4$ enzyme $/ \mathrm{kg}$ were effective to improve the dry matter and protein digestibility as well as metabolizable energy of PKC (Sinurat et al. 2013).

In this experiment, each ingredient (PKC and FPKC) was mixed with a basal diet with the ratio 50:50 and $2 \%$ ash insoluble ash (celite) as indicator. Five (5) dietary treatments were mixed for the digestibility trial, i.e., 1. Basal diet, 2. PKC without enzyme supplementation, 3. FPKC without enzyme supplementation, 4. FPKC $+20 \mathrm{ml} \mathrm{BS} 4$ enzyme $/ \mathrm{kg}$ and 5 . FPKC $+2 \mathrm{~g}$ commercial enzyme $/ \mathrm{kg}$. Each diet was fed ad libitum to 6 (six) male broiler chickens aged $28 \mathrm{~d}$ reared in individual wire cages.

Three days after feeding the test diets, excreta were collected by placing plastic trays underneath each cage in order to measure the metabolisable energy (AME) of test ingredients. The excreta was dried in oven at $70{ }^{\circ} \mathrm{C}$ and its gross energy was determined with bomb calorimeter. Six (6) replicates were assigned for each test diet for the AME determination.

The digestibility of the amino acids in the PKC and the FPKC were measured following the procedure described by Ravindran et al. (2005). Six (6) days after feeding the test diet, the animals were sacrificed by $\mathrm{CO}_{2}$ asphyxiation and the digesta in the ileal was collected into plastic containers, pooled within the same diet and immediately kept in the freezer for further chemical analyses. The frozen ileal digesta were freeze-dried prior to analyses of amino acids. Diets and the digesta were analysed for dry matter, AIA and crude protein according to procedures of AOAC (2005) while amino acids analyses were carried out by HPLC at Bogor Agricultural University laboratory. 


\section{Calculations}

Apparent ileal amino acid digestibility and AME were calculated following the formula:

Amino acid digestibility coefficient of the diet:

$=((\mathrm{AA} / \mathrm{AIA}) \mathrm{d}-(\mathrm{AA} / \mathrm{AIA}) \mathrm{i}) /(\mathrm{AA} / \mathrm{AIA}) \mathrm{d}$ X 100\%

Where:

(AA / AIA $) d=$ ratio of amino acid to acid-insoluble ash in the diet,

(AA/AIA)i = ratio of amino acid to acid-insoluble ash in the ileal digesta.

The amino acid digestibility of test ingredient:

$=(2 \mathrm{X}$ AA digestibility of test diet $)-$ AA digestibility of basal diet

And the calculation of the metabolizable energy (AME) was calculated as follow:

AME of diet $=$ GE diet $-(($ AIA in diet $/$ AIA in Excreta) X GE in Excreta)

The AME of the test ingredient:

$=(2 \mathrm{X}$ AME of test diet $)-\mathrm{AME}$ of the basal diet

Where:

$\mathrm{ME}=$ Apparent metabolisable energy $(\mathrm{kcal} / \mathrm{kg})$

$\mathrm{GE}=$ Gross energy $(\mathrm{kcal} / \mathrm{kg})$

AIA $=$ Acid insoluble ash $(\%)$

\section{Substitution of soybean meal with fermented PKC in laying hens diet}

A feeding trial was carried out to study the effect of substituting soya bean meal with enzymessupplemented FPKC (EFPKC) in the diet on the performance of laying hens. The FPKC was supplemented with BS4 enzymes at $20 \mathrm{ml} / \mathrm{kg}$ FPKC and its nutritive values (i.e., the $\mathrm{AME}$ and the ileal digestible amino acids values obtained from the digestibility trial) were used in the formulation of the diets, while nutrient values of other ingredients were based on the normal values used in commercial diet formulation in Indonesia. Five dietary treatments, i.e., 1. Control diet (without EFPKC), 2. Diet with $25 \%$ substitution of SBM (substituted with EFPKC), 3. Diet with $50 \%$ substitution of SBM (substituted with EFPKC), 4. Diet with $75 \%$ substitution of SBM (substituted with EFPKC) and 5. Diet with 100\% substitution of SBM (substituted with EFPKC). In order to maintain the similar nutrient values of the treatment diets, reduction of SBM in diets were followed by an increase in the EFPKC level. All diets were formulated with similar nutrient levels, i.e., ME $2650 \mathrm{kcal} / \mathrm{kg}$, crude protein $17 \%$, Ca $4.1 \%$, Available P $0.35 \%$,

Table 1. Ingredients of the experimental diets in the feeding trial (\%)

\begin{tabular}{lccccc}
\hline \hline Ingredients & Control & $\begin{array}{c}25 \% \text { SBM } \\
\text { Substituted }\end{array}$ & $\begin{array}{c}50 \% \text { SBM } \\
\text { Substituted }\end{array}$ & $\begin{array}{c}75 \% \text { SBM } \\
\text { Substituted }\end{array}$ & $\begin{array}{c}100 \% \text { SBM } \\
\text { Substituted }\end{array}$ \\
\hline Maize & 48.45 & 52.41 & 46.790 & 50.58 & 47.98 \\
Hominy/corn bran & 17 & 7.86 & 9.730 & 0.84 & 1 \\
Calcium carbonate & 9.37 & 9.00 & 8.480 & 7.96 & 7.19 \\
Soya bean meal & 20 & 15.00 & 10.000 & 5 & 0 \\
Fermented PKC + Enzyme (EFPKC) & 0 & 9 & 15 & 23 & 27.7 \\
Meat and bone meal & 3.61 & 5.00 & 7.000 & 9 & 12 \\
DCP & 0.42 & 0.00 & 0.00 & 0.00 & 0.00 \\
Vegetable oil & 0.5 & 0.85 & 2.000 & 2.5 & 3 \\
DL Methionine & 0.18 & 0.26 & 0.290 & 0.31 & 0.37 \\
L-Lysine & 0 & 0.15 & 0.240 & 0.34 & 0.29 \\
Vitamin mixture & 0.03 & 0.03 & 0.03 & 0.03 & 0.03 \\
Mineral mixture & 0.04 & 0.04 & 0.04 & 0.04 & 0.04 \\
Sodium Bicarbonate & 0.1 & 0.1 & 0.1 & 0.1 & 0.1 \\
Salt & 0.2 & 0.2 & 0.2 & 0.1 & 0.1 \\
Choline Chloride & 0.1 & 0.1 & 100.0 & 0.1 \\
\hline Total & 100.0 & 100.0 & & 0.1 \\
\hline
\end{tabular}


digestible lysine $0.702 \%$, digestible methionine $0.387 \%$, digestible methionine + cystine $0.600 \%$ and digestible tryptophane $0.164 \%$. The crude fibre of the diets according to the calculated values were 3.9, 4.7, 5.7, 6.4 and $7.1 \%$ for diet $1,2,3$ and 4 , respectively. The composition of the experimental diets is presented in Table 1.

Each diet was fed to 24 (6 replicates of 4 birds/replicate) Isa Brown laying hens aged 51 weeks old. All birds were placed in individual cages, but each four birds were equiped with one feeder. Therefore, 4 birds were considered as a replicate. Feed and water were given ad libitum and the trial was lasted for 8 (eight) weeks. Performance of the laying hens such as egg production (HD dan $\mathrm{HH}$ ), feed intake, and feed conversion ratio were recorded weekly. Egg qualities (yolk color score, HU and egg shell thickness) were determined at 5 weeks after treatment. Body weight changes due to the treatments were also determined by weighing the birds individually before and after treatment. The data were analysed with analyses of variance in a completely randomized design (5 treatments $\mathrm{x} 6$ replicates). Differences between treatments were examined with Duncan multiple range test when the analyses of variance showed a significant difference at $\mathrm{P}<0.05$ (Steel \& Torrie 1997).

\section{RESULTS AND DISCUSION}

\section{Enrichment of nutritional values of palm kernel cake (PKC) by fermentation and enzyme supplementation}

As shown in Table 2, fermentation of PKC with $A$. niger reduced the crude fibre slightly, increased the crude protein from $14.70 \%$ to $20.04 \%$ or $36.3 \%$ improvement. Most of the amino acids such as aspartic acid, glutamic acid, serine, histidine, alanine, tyrosine, methionine, valine, phenylalanine, isoleucine, leucine, lysine and tryptophan contents were also increased after fermentation. However, threonine and arginine contents were decreased by fermentation process. This result was in contrast to the report of Muhammad and Oleyede (2009) which showed that fermentation of Terminalia catappa seed meal with $A$. niger reduced almost all the amino acids content, except the glutamic acid, alanine and phenylalanine. Improvements on the nutrient values of the FPKC was mainly as the effect of $A$. niger cells proliferation and some metabolites such as enzymes produced during the growing process (Supriyati et al. 1998).

Table 2. Crude fibre, Protein and amino acids composition of palm kernel cake (PKC) and fermented PKC (FPKC) with A. niger (\% dry matter)

\begin{tabular}{lccc}
\hline \hline & $\begin{array}{c}\text { Palm kernel } \\
\text { cake (PKC) }\end{array}$ & $\begin{array}{c}\text { Fermented palm } \\
\text { kernel cake (FPKC) }\end{array}$ & $\begin{array}{c}\text { Improvement due } \\
\text { to fermentation }(\%)\end{array}$ \\
\hline Crude Fibre & 15.09 & 14.76 & -2.2 \\
Crude Protein & 14.70 & 20.04 & 36.3 \\
Aspartic acid & 1.251 & 1.525 & 21.9 \\
Glutamic acid & 2.869 & 3.148 & 9.7 \\
Serine & 0.669 & 0.758 & 13.4 \\
Histidine & 0.333 & 0.394 & 18.3 \\
Glycine & 0.424 & 0.757 & 78.2 \\
Threonine & 0.695 & 0.473 & -32.0 \\
Arginine & 1.191 & 1.137 & -4.6 \\
Alanine & 0.631 & 0.983 & 55.7 \\
Tyrosine & 0.311 & 0.602 & 93.3 \\
Methionine & 0.205 & 0.216 & 5.2 \\
Valine & 0.731 & 0.857 & 17.3 \\
Phenilalanine & 0.677 & 0.766 & 13.3 \\
Isoleucine & 0.475 & 0.559 & 17.6 \\
Leucine & 0.865 & 0.968 & 12.0 \\
Lysine & 0.614 & 0.678 & 10.4 \\
Tryptophan & 0.102 & 0.221 & 17.2 \\
\hline
\end{tabular}


The ileal amino acids digestibility (IAAD) of palm kernel cake (PKC) and fermented palm kernel cake (FPKC) with or without enzyme supplementation are shown in Table 3. Fermentation of the PKC increased the crude protein digestibility and most of the IAAD, except the IAAD of serine, threonine, alanine, valine and phenyalanine. Muangkeow and Chinajariyawong (2009) also reported an increase in the true amino acids digestibility except for arginine of the PKC after fermentation. Supplementation of the BS4 enzyme or the commercial enzyme into the FPKC improved the protein digestibility and all the amino acids digestibilities. The ileal crude protein digestibility of the FPKC were greater when supplemented with BS4 enzyme (91.39\%) as compared to the commercial enzyme $(65.26 \%)$. Some amino acids, particularly the indispensable amino acids (arginine, histidine and leucine) digestibility values were greater than $100 \%$, which is difficult to explain. Perhaps, it could be explained that enzyme supplementation in to the FPKC also increased the amino acids digestibility of other feedstuffs included in the basal diet, since the tested ingredients were mixed with a basal diet $(50: 50)$ in this assay and these increments were counted as the improvement of the FPKC. More studies or assays should be performed to explain this. An IAAD assay which use the tested ingredient as the sole source of protein in the diet as reported by Huang et al. (2006) could be a good tool to explain this.

The results showed that the tryptophan digestibility of the PKC and the FPKC were negatives, i.e., $-25.26 \%$ and $-40.24 \%$, respectively. It could not be explained why this happened. Perhaps, more replicates of laboratory analyses should be performed to validate the values. Nwokolo et al. (1976) and Muangkeow \& Chinajariyawong (2009) did not report the tryptophan digestibility value of the PKC in poultry. Sulabo et al. (2013) reported high values of tryptophan apparent ileal digestibility $(82.3-84.1 \%)$ of palm kernel cake measured in growing barrows. However, the FPKC supplemented with enzymes, either BS4 or the commercial enzyme showed high tryptophan digestibilities, i.e., 107.53 and $92.11 \%$, respectively.

As shown in Table 3, the AME value of the PKC was decreased $(\mathrm{P}<0.05)$ after the fermentation. The AME of the fermented PKC was increased when supplemented with the BS4 enzyme, but not with the

Table 3. Metabolisable energy (AME), Ileal protein- and amino acids digestibility coefficient of palm kernel cake (PKC) and fermented PKC supplemented with enzymes

\begin{tabular}{lcccc}
\hline \hline Nutrients & PKC* & FPKC* & FPKC+BS4* & FPKC+CE* \\
\hline AME $^{*}$ (Kcal/kg) & $2074^{\mathrm{a}}$ & $1788^{\mathrm{b}}$ & $1867^{\mathrm{ab}}$ & $1752^{\mathrm{ab}}$ \\
Protein digestibility, \% & 34.08 & 49.79 & 91.39 & 65.26 \\
Aspartic acid, \% & 33.39 & 49.19 & 85.42 & 95.94 \\
Glutamic acid, \% & 48.07 & 65.43 & 89.46 & 101.21 \\
Serine, \% & 49.10 & 44.81 & 80.89 & 92.24 \\
Histidine, \% & 56.73 & 71.45 & 96.83 & 106.07 \\
Glycine, \% & 48.21 & 55.24 & 81.64 & 96.37 \\
Threonine, \% & 42.65 & 30.87 & 77.05 & 88.50 \\
Arginine, \% & 74.16 & 66.14 & 87.85 & 102.61 \\
Alanine, \% & 55.84 & 47.45 & 77.98 & 88.43 \\
Tyrosine, \% & 37.31 & 57.36 & 88.65 & 98.51 \\
Methionine, \% & 44.42 & 64.83 & 71.17 & 99.83 \\
Valine, \% & 66.82 & 61.67 & 85.36 & 96.01 \\
Phenyalanine, \% & 67.98 & 62.45 & 81.49 & 93.34 \\
Iso-leucine, \% & 30.20 & 91.92 & 116.97 & 134.64 \\
Leucine, \% & 23.16 & 91.03 & 114.60 & 131.14 \\
Lysine, \% & 60.39 & 62.20 & 80.23 & 84.44 \\
Tryptophan, \% & -25.56 & -40.24 & 107.53 & 92.11 \\
\hline
\end{tabular}

${ }^{\#} \mathrm{AME}=$ Apparent metabolisable energy (measured with 6 replicates) and different superscript indicated significantly different $(\mathrm{P}<0.05)$

$* \mathrm{PKC}=$ palm kernel cake; FPKC $=$ fermented PKC; BS4 = BS4 enzyme; $\mathrm{CE}=$ commercial (multi) enzyme 
commercial enzyme. This result indicated that the BS4 enzyme is more suitable to improve the AME values of the FPKC. Muangkeow \& Chinajariyawong (2009) reported also that the AME of the palm kernel meal was decreased from 2202 to $2080 \mathrm{kcal} / \mathrm{kg}$, after fermented with $A$. wentii. Similar trend was also occurred on the TMEn values as the effect of the fermentation. However, Bintang et al. (1999) reported an increase on the AME of the PKC after fermented with A. niger measured on growing ducks. Similar process of fermentation was also reported to increase the AME values of palm oil sludge or solid heavy phase measured on laying hens (Sinurat et al. 2007).

Both enzymes (the BS4 and the commercial enzyme) have been reported effectively to increase the dry matter digestibility and the TME of palm oil sludge, but only the BS4 enzyme was effective to increase the protein digestibility (Pasaribu et al. 2009).

\section{The effect of substitution of dietary soybean meal with enzyme- suplemented fermented palm kernel cake (EFPKC) on the performance of laying hens}

The performance of the laying hens during the 8 (eight) weeks production period is presented in Table 4 , 5 and 6. As shown in Table 4, the body weight of birds before the treatments were similar $(\mathrm{P}>0.05)$. However, after eight (8) weeks feeding trial the body weight of the birds were significantly $(\mathrm{P}<0.001)$ affected by the dietary treatments. All the birds showed a reduction in body weight or a negative body weight changes. The more the soybean meal substituted by the EFPKC, the more the reduction in body weight $(\mathrm{P}<0.002)$, although only significant at $100 \%$ SBM substitution.

Unlike in the broiler production, the reduction in body weight on laying hens is not an issue, as far as the egg production and the feed efficiency are not impaired. The reduction in body weight is a reflection of inadequate nutrients, especially the energy and the protein or amino acids intake. In this experiment, the highest body weight loss (-309.3 g/bird/8 weeks) was found on birds fed without soybean meal or $100 \%$ substitution of soybean meal with the EFPKC. All the experimental diets were formulated to have a similar nutrient contents such as the AME, crude protein, digestible amino acids, $\mathrm{Ca}$ and available $\mathrm{P}$ that met the requirement of laying hens. Therefore, the body weight lost during the experiment may be due to a reduction in feed intake, hence nutrients intake (Table 5). There are many factors that affect the feed intake in laying hens. Some of the dietary factors include the nutritional balance, flavor and the presence of an antinutritional substances. Results of this study showed that the more soybean meal substituted with the EFPKC, the less the feed intake. It seems that the flavor of the EFPKC reduced the palatability of the diet. Some reports showed that inclusion of high levels of fermented feed (Engberg et al. 2009) or fermented feedstuffs such as palm kernel meal (Iyayi \& Aderolu 2004), cassava peel (Osei et al. 1990), palm oil sludge (Fenita et al. 2010) in the diet reduced the feed intake of laying hens. Although some authors also repoted that inclusion of fermented feedstuffs in the diet did not affect the feed intake of laying hens (Loh et al. 2007; Dairo \& Fasuyi 2008).

The average hen-day egg production, feed intake and the feed conversion ratio of the birds were significantly $(\mathrm{P}<0.001)$ affected by the substitution of the soy bean meal with the EFPKC. As shown in Table 5 , the results showed that the substitution of $25 \%$ soybean meal in the diet did not significantly $(\mathrm{P}>0.05)$ impair the HD egg production, the FCR and the egg weight, although the feed intake was significantly $(\mathrm{P}<0.05)$ decreased. Further substitution of the soybean meal to $50 \%$ has shown a slightly reduction in the HD egg production, FCR and the egg weight, although the differences with the control were not statistically significant $(\mathrm{P}>0.05)$. However, substitution of $75 \%$ and $100 \%$ soybean meal with the EFPKC has shown a significantly $(\mathrm{P}<0.05)$ reduction in the $\mathrm{HD}$ egg production and impaired the FCR, but not on the the egg weight $(\mathrm{P}>0.05)$. The results also showed that the feed intake was significantly $(\mathrm{P}<0.001)$ reduced when the soybean meal was substituted with the EFPKC. The more the soybean meal was substituted with the EFPKC, the more the feed intake was reduced.

Table 4. Body weight changes of laying hens after fed with enzyme supplemented-FPKC to replace soy bean meal for 8 weeks

\begin{tabular}{lccc}
\hline \hline Treatments & $\begin{array}{c}\text { Initial body weight at } \\
\text { 52 weeks of age, }\end{array}$ & $\begin{array}{c}\text { Final body weight at } 60 \\
\text { weeks of age, } \mathrm{g}\end{array}$ & Body weight change, g \\
\hline Control (100\% SBM) & 1924 & $1854^{\mathrm{a}}$ & $69.7^{\mathrm{a}}$ \\
$25 \%$ SBM substituted & 1920 & $1810^{\mathrm{b}}$ & $-101.3^{\mathrm{a}}$ \\
$50 \%$ SBM substituted & 1916 & $1790^{\mathrm{b}}$ & $-127.0^{\mathrm{a}}$ \\
$75 \%$ SBM substituted & 1910 & $1672^{\mathrm{b}}$ & $-185.7^{\mathrm{a}}$ \\
$100 \%$ SBM substituted & 1857 & $1611^{\mathrm{c}}$ & $-309.3^{\mathrm{b}}$ \\
Significance (P) & 0.702 & 0.0001 & 0.002 \\
\hline
\end{tabular}


Table 5. Performances of laying hens fed with soya bean meal substituted with enzyme supplemented- FPKC for 8 weeks

\begin{tabular}{lcccc}
\hline \hline Treatments & $\begin{array}{c}\text { Egg production } \\
(\% \text { HD) }\end{array}$ & Feed intake $(\mathrm{g} / \mathrm{b} / \mathrm{d})$ & FCR $(\mathrm{g} / \mathrm{g})$ & Egg Weight (g/egg) \\
\hline Control (100\% SBM) & $90.7^{\mathrm{a}}$ & $117.9^{\mathrm{a}}$ & $2.02^{\mathrm{c}}$ & $64.8^{\mathrm{a}}$ \\
$25 \%$ SBM substituted & $90.6^{\mathrm{a}}$ & $111.4^{\mathrm{b}}$ & $1.97^{\mathrm{c}}$ & $62.6^{\mathrm{a}}$ \\
$50 \%$ SBM substituted & $87.8^{\mathrm{a}}$ & $111.5^{\mathrm{b}}$ & $2.08^{\mathrm{c}}$ & $61.6^{\mathrm{a}}$ \\
$75 \%$ SBM substituted & $75.9^{\mathrm{b}}$ & $106.6^{\mathrm{b}}$ & $2.36^{\mathrm{b}}$ & $60.1^{\mathrm{a}}$ \\
$100 \%$ SBM substituted & $63.8^{\mathrm{c}}$ & $102.3^{\mathrm{c}}$ & $2.75^{\mathrm{a}}$ & $60.6^{\mathrm{a}}$ \\
Significance (P) & 0.001 & 0.0001 & 0.001 & 0.062 \\
\hline
\end{tabular}

Different superscript in the same column indicated significantly different $(\mathrm{P}<0.05)$.

Table 6. Egg quality of hens as affected by replacing soy bean meal with EFPKC in the diet

\begin{tabular}{lccc}
\hline \hline Treatments & Egg shell thickness, mm & HU & Yolk Color Score \\
\hline Control (100\% SBM) & $0.34^{\mathrm{a}}$ & $93.5^{\mathrm{a}}$ & $6.3^{\mathrm{b}}$ \\
$25 \%$ SBM replaced & $0.32^{\mathrm{abc}}$ & $96.8^{\mathrm{a}}$ & $8.2^{\mathrm{a}}$ \\
$50 \%$ SBM replaced & $0.33^{\mathrm{ab}}$ & $94.8^{\mathrm{a}}$ & $7.9^{\mathrm{a}}$ \\
$75 \%$ SBM replaced & $0.31^{\mathrm{c}}$ & $95.7^{\mathrm{a}}$ & $8.2^{\mathrm{a}}$ \\
$100 \%$ SBM replaced & $0.32^{\mathrm{bc}}$ & $95.8^{\mathrm{a}}$ & $8.0^{\mathrm{a}}$ \\
Significance (P) & 0.013 & 0.348 & 0.001 \\
\hline
\end{tabular}

Some reports have shown that substitution of $25 \%$ (Ojewola \& Ozuo 2006) or 50\% (Dairo \& Fasuyi 2008) and even $100 \%$ (Mirnawati et al. 2011) soy bean meal with fermented palm kernel cake in the diet did not show negative effects on the performance of broilers. The present study, however, suggests that 25 to $50 \%$ of the soybean meal could be substituted with the EFPKC in the laying hens diet.

As shown in Table 6, the substitution of the soybean meal with the EFPKC in laying hens diet did not significantly $(\mathrm{P}>0.05)$ affect the egg shell thickness and the HU, but significantly $(\mathrm{P}<0.05)$ affect the yolk color scores. The yolk color scores were significantly improved when the EFPKC was included in the diet. Previous study also reported a similar trend when the PKC (Zanu et al. 2011) or the fermented PKC (Fenita et al. 2010) or other palm oil by-product such as palm oil sludge (Sinurat et al. 2007) are included in the diet of laying hens. Palm oil fruits contain high carotenoid as pigment sources (Sundram et al. 2003). Therefore, palm oil by products may also contain some carotenoids that contribute to improve the yolk color of eggs produced by hens fed with the fermented palm kernel cake.

\section{CONCLUSION}

This study concluded that the fermentation of palm kernel cake with A. niger increased the crude protein and most of the amino acids contents except the threonine and arginine, but decrease its AME. Supplementation of enzymes (BS4 or CE) improved the ileal amino acids digestibilities of the fermented PKC. However, only BS4 enzymes increased the AME of the fermented PKC.

About $25 \%$ to $50 \%$ of the soybean meal in the diet could be substituted by the enzyme- supplemented palm kernel cake (EFPKC) without any detrimental effect on the performances of laying hens.

\section{ACKNOWLEDGEMENT}

The authors appreciate all the technicians who provided the fermentation and enzyme productions and helped the farm experiment. Those were Mr. Helmi Hamid, Ms. Emi Sujatmika, Ms. Ema Frederick, the late Mr. Haryono and Mr. Audi Tangkudung. This project was funded by Kementerian Riset dan Teknologi Republik Indonesia through PKPP project. 


\section{REFERENCES}

[AOAC] Association of Official Analytical Chemists. 2005. Official methods of analysis of AOAC. Gaithersburg (MA): AOAC International.

Azman MA And Yilmaz M. 2005. The growth performance of broiler chicks fed with diets containing cottonseed meal supplemented with lysine. Revue Méd Vét. 156:104-106.

Chong CH, Zulkifli I, Blair R. 2008. Effects of dietary inclusion of palm kernel cake and palm oil and enzyme supplementation on performance of laying hens. AsianAust J Anim Sci. 21:1053-1058.

Ciurescu G. 2009. Efficiency of soybean meal replacement by rapeseed meal and/or canola seeds in commercial layer diets. Arc Zootech. 12:27-33.

Clarke E, Wiseman J. 1999. Nutritional value of soya products for non-ruminant farm animals. Singapore: American Soybean Association.

Dairo FAS, Fasuyi AO. 2008. Evaluation of fermented palm kernel meal and fermented copra meal proteins as substitute for soybean meal protein in laying hens diets. J Central Eur Agric. 9:35-44.

[Ditjen PKH] Direktorat Jenderal Peternakan dan Kesehatan Hewan. 2013. Realisasi impor bahan pakan Tahun 2012. Jakarta (Indones): Direktorat Jenderal Peternakan dan Kesehatan Hewan.

Engberg RM, Hammershøj M, Johansen NF, Abousekken MS, Steenfeldt S. Jensen BB. 2009. Fermented feed for laying hens: effects on egg production, egg quality, plumage condition and composition and activity of the intestinal microflora. Br Poult Sci. 50:228-239.

Fenita Y, Santoso U, Prakoso H. 2010. Pengaruh lumpur sawit fermentasi dengan Neorospora sp. terhadap performans produksi dan kualitas telur. JITV. 15:88-96.

Iyayi EA, Aderolu ZA. 2004. Enhancement of the feeding value of some agroindustrial by-products for laying hens after their solid state fermentation with Trichoderma viride. Afr J Biotechnol. 3:182-185.

Leeson S, Atteh JO, Summers JD. 1987. The replacement value of canola meal for soybean meal in poultry diets. Can J Anim Sci. 67:151-158.

Iyayi EA, Davies BI. 2005. Effect of enzyme supplementation of palm kernel meal and brewer's dried grain on the performance of broilers. Int J Poult Sci 4:76-80.

Loh TC, Law FL, Foo HL, Goh YM, Zulkifli I. 2007. Effects of feeding a fermented product on egg production, faecal microflora and faecal $\mathrm{pH}$ in laying hens. J Anim Feed Sci. 16:452-462.

Mirnawati, Rizal Y, Marlida Y, Kompiang IP. 2011. Evaluation of palm kernel cake fermented by Aspergillus niger as substitute for soybean meal protein in the diet of broiler. Int J Poult Sci. 10:537-541.
Muangkeow N, Chinajariyawong C. 2009. Determination of true amino acid digestibility and metabolizable energy in fermented palm kernel meal with Aspergillus wentii TISTR 3075 for chickens. Walailak J Sci Technol. 6:231-241.

Muhammad NO, Oloyede OB. 2009. Protein fractions and amino acid profile of Aspergillus niger-fermented Terminalia catappa seed meal. Afr J Microbiol Res. 3:101-104.

Nwokolo, EN, Bragg DB, Saben HS 1976. The availability of amino acids from palm kernel, soybean, cotton seed and rape seed meal for the growing chick. Poult Sci. 55:2300-2304.

Nwokolo EN, Bragg DB, Saben HS. 1977. A nutritive evaluation of palm kernel meal for use in poultry rations. Trop Sci. 19:147-154.

Onwudike OC. 1986. Palm kernel meal as a feed for poultry: 1. Composition of palm kernel meal and availability of its amino acids to chicks. Anim Feed Sci Technol. 16:179-186.

Ojewola GS, Ozuo UK. 2006. Evaluation of palm kernel meal as substitute for soyabean meal in the diet of growing cockerels. Int J Poult Sci. 5:401-403.

Osei SA, Asiamah M, Atuahene CC. 1990. Effects of fermented cassava peel meal on the performance of layers. Anim Feed Sci Technol. 29:295-301.

Pasaribu T, Sinurat AP, Purwadaria T, Ketaren P. 2009. Peningkatan nilai gizi solid heavy phase sebagai pengganti jagung dalam pakan unggas. JITV. 14:167176.

Pesti GM, Bakalli RI, Driver JP, Sterling KG, Hall LE Bell EM. 2003. Comparison of peanut meal and soybean meal as protein supplements for laying hens. Poult Sci. 82:1274-1280.

Purwadaria T, Nirwana N, Ketaren PP, Pradono DI, Widyastuti Y. 2003. Synergistic activity of enzymes produced by Eupenicillium javanicum and Aspergillus niger NRRL 337 on palm oil factory wastes. Biotropia. 20:1-10.

Ravindran V, Hendriks WH, Thomas DV, Morel PCH, Butts CA. 2005. Comparison of the ileal digestibility of amino acids in meat and bone meal for broiler chickens and growing rats. Int J Poult Sci. 4:192-196.

Saenphoom P, Liang JB, Ho YW, Loh TC, Rosfarizan M. 2013. Effects of enzyme treated palm kernel expeller on metabolizable energy, growth performance, villus height and digesta viscosity in broiler chickens. AsianAust J Anim Sci. 26:537-544.

Shi SR, Lu J, Tong HB, Zou JM, Wang KH. 2012. Effects of graded replacement of soybean meal by sunflower seed meal in laying hen diets on hen performance, egg quality, egg fatty acid composition, and cholesterol content. J Appl Poult Res. 21:367-374. 
Sinurat AP, Purwadaria T, Bintang IAK, Pasaribu T. 2007. Peningkatan nilai gizi solid heavy phase dalam ransum unggas sebagai pengganti jagung. JITV. 12:87-95.

Sinurat AP, Purwadaria T, Bintang IAK, Pasaribu, T. 2013. Evaluasi nilai gizi solid heavy phase sebagai pengganti jagung dalam ransum broiler. JITV. 11:167-174.

Steel RGD, Torrie JH. 1997.Principles and Procedures of Statistics: A Biometrical Approach. 3rd ed. New York (USA): Mc. Graw Hill Co., Inc.

Sundram K, Sambanthamurthi R, Tan YA. 2003. Palm fruit chemistry and nutrition. Asia Pacific J Clin Nutr. 12:355-362.

Sundu B, Kumar A, Dingle J. 2006. Palm kernel meal in broiler diets: Effect on chicken performance and health. World Poult Sci J. 62:316-325.
Sue TT, Awaludin R. 2005. Palm kernel cake and pellet. In Basiron Y, Darus A, Ngan MA, Weng CK. Eds. Palm kernel products-characteristics and applications. Malaysian Palm Oil Board. Kuala Lumpur (Malaysia): Ministry of Plantation Industries and Commodities.

Sulabo RC, Ju WS, Stein HH. 2013. Amino acid digestibility and concentration of digestible and metabolizable energy in copra meal, palm kernel expellers, and palm kernel meal fed to growing pigs. J Anim Sci. 91:13911399.

Supriyati, Pasaribu T, Hamid H, Sinurat A.1998. Fermentasi bungkil inti sawit secara substrat padat dengan menggunakan Aspergillus niger. JITV. 3:165-170.

Zanu HK, Abangiba J, Arthur-Badoo W, Akparibo AD, Sam R. 2011. Laying chickens' response to various levels of palm kernel cake in diets. Int J Livest Prod. 3:12-16. 